DOI: $10.15193 /$ zntj/2017/112/201

\author{
PIOTR SZYMAŃSKI, DANUTA KOŁOŻYN-KRAJEWSKA, \\ URSZULA SIEKIERKO, ANETA KERN-JĘDRYCHOWSKA
}

\title{
EFEKTYWNOŚĆ BAKTERII STAPHYLOCOCCUS CARNOSUS W REDUKCJI AZOTANU(III) SODU W UKLADZIE MODELOWYM
}

\author{
Streszczenie
}

Celem pracy była ocena wpływu wybranych warunków i oddziaływania substancji dodatkowych stosowanych w produkcji farszów mięsnych na redukcję azotanu(III) sodu przez bakterie Staphylococcus carnosus, pozyskane ze szczepionki przemysłowej przeznaczonej do produkcji wędlin surowo dojrzewających (Bactoferm S-B-61). Badania przeprowadzono w układzie modelowym, który stanowiło płynne podłoże białkowe TSB. Kultura bakteryjna była rozmnażana na płynnym podłożu TSB w ciągu $20 \mathrm{~h}$, w temp. $30^{\circ} \mathrm{C}$. Do poszczególnych doświadczeń pobierano bakterie z trzeciego pasażu. Badano wpływ $S$. carnosus na redukcję azotanu(III) sodu w określonych warunkach (czas, temperatura, liczba początkowa bakterii). Dodatkowe zastosowano chlorek sodu i wielofosforany. W każdym z doświadczeń przed i po inkubacji wykonywano oznaczenia zawartości azotanów(III) i azotanów(V), liczby bakterii S. carnosus, pH i potencjału redox. Badania wykonano w trzech równoległych powtórzeniach. Na podstawie przeprowadzonych badań wykazano, że szczep bakterii $S$. carnosus redukował azotan(III) sodu w temp. 20 $40{ }^{\circ} \mathrm{C}$. Zwiększenie początkowej liczby bakterii do $10^{7} \mathrm{jtk} / \mathrm{cm}^{3}$ wpływało istotnie na redukcję azotanów(III). Wraz ze wzrostem liczby bakterii obserwowano wzrost stopnia kwasowości podłoża i obniżenie wartości potencjału oksydacyjno-redukcyjnego układu modelowego. Chlorek sodu i wielofosforany działały hamująco na wzrost i aktywność bakterii w zakresie redukcji azotanu(III) sodu. Stwierdzono, że szczep bakterii S. carnosus redukuje azotan(III) sodu, ale tylko w określonych warunkach środowiskowych.

Słowa kluczowe: azotany(III), peklowanie mięsa, Staphylococcus carnosus, redukcja azotanów(III)

Dr inż. P. Szymański, mgr inż. U. Siekierko, mgr inż. A. Kern-Jędrychowska, Zakład Technologii Mięsa i Ttuszczu, Instytut Biotechnologii Przemystu Rolno-Spożywczego im. prof. Wacława Dąbrowskiego, ul. Jubilerska 4, 04-190 Warszawa, prof. dr hab. D. Kołożyn-Krajewska, Katedra Technologii Gastronomicznej i Higieny Żywności, Wydz. Nauk o Żywieniu Człowieka i Konsumpcji, Szkoła Główna Gospodarstwa Wiejskiego w Warszawie, ul. Nowoursynowska 159 C, 02-776 Warszawa.

Kontakt:piotr.szymanski@ibprs.pl 


\section{Wprowadzenie}

Poprawa higieny podczas uboju zwierząt, rozbioru mięsa $\mathrm{i}$ jego przetwarzania wpływa pozytywnie na jakość mikrobiologiczną surowca i produktów, ale przypuszcza się, że może mieć niekorzystny wpływ na przebieg procesu peklowania mięsa, szczególnie w przypadku produktów poddawanych obróbce cieplnej [17, 18].

Dotychczasowe badania wskazują na możliwość zastosowania szczepu Staphylococcus carnosus ATCC 51365 do poprawy efektywności procesu peklowania azotanowego(III) mięsa [18]. Uzyskane wyniki badań są zadowalające, zwłaszcza w zakresie możliwości zdynamizowania reakcji nitrozylowania barwników hemowych mięsa i poprawy barwy produktów mięsnych poddawanych obróbce cieplnej. Z przeprowadzonych doświadczeń wynika, że wzbogacenie naturalnej mikroflory mięsa wybranymi szczepami bakterii denitryfikujących ma wpływ na przemiany azotanów(III) podczas peklowania i w efekcie przyczynia się do ograniczenia resztkowego azotanu(V) w wyrobie gotowym. Bardziej efektywne wykorzystanie azotanów(V) powstałych z azotanów(III) w reakcjach dysmutacji ma obecnie istotne znaczenie, szczególnie z uwagi na tendencje ograniczania dodatku substancji peklujących do produkcji wędlin. Opracowywana technologia wymaga optymalizacji w zakresie zmniejszenia w produkcie początkowej zawartości azotanów(III) powstałych ze zredukowanych przez bakterie azotanów(V) [17, 18]. Jednym ze sposobów może być zastosowanie bakterii deniryfikujących, które wykazują wysoką aktywność w zakresie redukcji azotanów(III).

Początkowa dawka azotanów(III), chlorek sodu i polifosforany stosowane w produkcji wędlin parzonych mogą mieć wpływ na aktywność enzymatyczną bakterii i redukcję azotanów(III).

Celem pracy była ocena wpływu wybranych warunków i oddziaływania substancji dodatkowych stosowanych w produkcji farszów mięsnych na redukcję azotanu(III) sodu przez bakterie Staphylococcus carnosus, pochodzące ze szczepionki przemysłowej przeznaczonej do produkcji wędlin surowo dojrzewających.

\section{Material i metody badań}

Badania przeprowadzono w układzie modelowym, który stanowiło płynne podłoże białkowe TSB (Difco, USA, $\mathrm{pH}_{\text {podłoża }}=7,30 \pm 0,20$ ). W pracy zastosowano szczep bakterii denitryfikujących Staphylococcus carnosus pochodzący ze szczepionki przemysłowej Bactoferm S-B-61 (Chr. Hansen Holding A/S) przeznaczonej do produkcji wędlin surowych dojrzewających.

Kultura bakteryjna była rozmnażana na płynnym podłożu TSB w ciągu $20 \mathrm{~h}$, w temp. $30^{\circ} \mathrm{C}$. Do poszczególnych doświadczeń pobierano określoną ilość kultury $\mathrm{z}$ trzeciego pasażu. 
Badano wpływ S. carnosus na redukcję azotanu(III) sodu w określonych warunkach (czas, temperatura, liczba początkowa bakterii). Jako substancje dodatkowe zastosowano chlorek sodu i wielofosforany.

Wpływ temperatury określano w doświadczeniu, w którym do probówek z $9 \mathrm{~cm}^{3}$ podłoża TSB wprowadzano $10^{6} \mathrm{jtk} / \mathrm{g}$ S. carnosus oraz azotan(III) sodu w ilości $100 \mathrm{mg} / \mathrm{dm}^{3}$ pożywki (poziom stosowany w praktyce przemysłowej w produkcji wędlin parzonych). Następnie próbki inkubowano w temp. 4 - $45^{\circ} \mathrm{C}$ w ciągu $20 \mathrm{~h}$.

Wpływ czasu inkubacji i początkowej liczby bakterii określano w doświadczeniu, w którym do probówek z $9 \mathrm{~cm}^{3}$ podłoża TSB wprowadzano $10^{6} \mathrm{jtk} / \mathrm{g}$ lub $10^{7} \mathrm{jtk} / \mathrm{g}$ S. carnosus oraz azotan(III) sodu $\left(100 \mathrm{mg} / \mathrm{dm}^{3}\right)$. Następnie próbki inkubowano od 0 do $20 \mathrm{~h} \mathrm{w}$ temp. $30^{\circ} \mathrm{C}$, uznanej we wcześniejszym etapie badań za optymalną do redukcji azotanów(III) przez bakterie.

Wpływ chlorku sodu określano w doświadczeniu, w którym używano podłoży TSB o trzech zawartościach $\mathrm{NaCl}: 0,5 \%$ (normalna zawartość $\mathrm{NaCl}$ w podłożu TSB), 2,0 i 3,0\%. Do probówek z $9 \mathrm{~cm}^{3}$ każdego podłoża wprowadzano azotan(III) sodu $\left(100 \mathrm{mg} / \mathrm{dm}^{3}\right)$ oraz bakterie $S$. carnosus w ilości $10^{7} \mathrm{jtk} / \mathrm{g}$. Próbki inkubowano od 0 do $20 \mathrm{~h}$ w temp. $30^{\circ} \mathrm{C}$.

Wpływ wielofosforanów określano w doświadczeniu, w którym do podłoża TSB o zawartości 2,0 \% $\mathrm{NaCl}$ (poziom soli normalnie stosowany w produkcji wędlin parzonych) wprowadzano trifosforan sodu (Tari P 31) na poziomie odpowiadającym średniej zawartości naturalnego fosforu w mięsie chudym [20] oraz dodatkowo ilość fosforu odpowiadającą fosforowi dodawanemu do wędlin, na trzech różnych poziomach: $0,1,5$ i 3,0 $\mathrm{g} \mathrm{P}_{2} \mathrm{O}_{5} / \mathrm{dm}^{3}$. Całkowita zawartość fosforu w środowisku modelowym kształtowała się, w zależności od wariantu, na poziomie: 1,2 , 4,9 i $6,4 \mathrm{~g} \mathrm{P}_{2} \mathrm{O}_{5} / \mathrm{dm}^{3}$. Do $9 \mathrm{~cm}^{3}$ sporządzonego podłoża wprowadzano azotan(III) sodu w ilości $100 \mathrm{mg} / \mathrm{dm}^{3}$ oraz bakterie S. carnosus w ilości $10^{7} \mathrm{jtk} / \mathrm{g}$. Probówki inkubowano od 0 do $20 \mathrm{~h} \mathrm{w}$ temp. $30^{\circ} \mathrm{C}$.

W każdym z doświadczeń, przed inkubacją i po jej przeprowadzeniu, wykonywano oznaczenia: zawartości azotanów(III) i azotanów(V) zgodnie z PN-EN ISO 120143:2006 [13] z modyfikacją [15], liczby bakterii S. carnosus metodą płytkową (podłoże TSA firmy Oxoid, inkubacja w ciągu $72 \mathrm{~h}$ i temp. $30^{\circ} \mathrm{C}$ ), pH i potencjału redox aparatem Mettler Delta 350 z elektrodą InLab Redox Pro (Mettler Toledo, Anglia) i elektrodą szklano-kalomelową do pomiaru $\mathrm{pH}$. Badania wykonano w trzech równoległych powtórzeniach. Warianty kontrolne nie zawierały dodatku bakterii.

Do statystycznego opracowania wyników użyto programu Statgraphics Plus 4.1. Przeprowadzono jednoczynnikową analizę wariancji, a istotność różnic między wartościami średnimi analizowano testem Fishera $(\mathrm{p}=0,05)$. 


\section{Wyniki i dyskusja}

Wykazano, że temperatura inkubacji miała wpływ na redukcję azotanu(III) sodu przez bakterie Staphylococcus carnosus. Badany szczep bakterii redukował azotan(III) sodu w temp. $20-40{ }^{\circ} \mathrm{C}$. W próbkach inkubowanych w tym zakresie temperatur zawartość azotanu(III) sodu była istotnie mniejsza niż w wariancie kontrolnym (p s $0,05)$. Najwyższy stopień redukcji azotanów(III) przez bakterie zaobserwowano w temp. $30^{\circ} \mathrm{C}$. Po $20 \mathrm{~h}$ inkubacji prowadzonej w temp. $30^{\circ} \mathrm{C}$ stwierdzono redukcję azotanu(III) sodu na poziomie $37,4 \%$. Próby inkubowane w temp. $30{ }^{\circ} \mathrm{C}$ charakteryzowały się również najwyższą liczbą bakterii, co wskazuje, że takie warunki temperaturowe są optymalne do wzrostu bakterii. W wariancie kontrolnym bez dodatku szczepu bakteryjnego nie wykazano istotnej redukcji azotanu(III) sodu w stosunku do ilości wprowadzonej przed inkubacją (tab. 1).

Tabela 1. Stopień redukcji azotanu(III) sodu przez szczep Staphylococcus carnosus w ciągu 20 h inkubacji, determinowany temperaturą inkubacji

Table 1. Reduction degree of sodium nitrate(III) by Staphylococcus carnosus strain during $20 \mathrm{~h}$ of incubation determined by incubation temperature

\begin{tabular}{||c|c|c|c|c|c|c|c||}
\hline $\begin{array}{c}\text { Próba } \\
\text { Sample }\end{array}$ & $\begin{array}{c}\mathrm{T} \\
{\left[{ }^{\circ} \mathrm{C}\right]}\end{array}$ & $\begin{array}{c}* \text { S. carnosus } \\
\text { ATCC 51365 } \\
{\left[\log \mathrm{jtk} / \mathrm{cm}^{3}\right]}\end{array}$ & $\begin{array}{c}\mathrm{NaNO}_{3} \\
{\left[\mathrm{mg} / \mathrm{dm}^{3}\right]}\end{array}$ & $\begin{array}{c}\mathrm{NaNO}_{2} \\
{\left[\mathrm{mg} / \mathrm{dm}^{3}\right]}\end{array}$ & $\begin{array}{c}\mathrm{SR} \\
\mathrm{NaNO}_{2} \\
{[\%]}\end{array}$ & $\mathrm{pH}$ & $\begin{array}{c}\text { Redox } \\
{[\mathrm{mv}]}\end{array}$ \\
\hline $\mathrm{K}$ & - & - & 0,0 & $102,5^{\mathrm{d}} \pm 1,1$ & - & $7,24^{\mathrm{f}} \pm 0,01$ & $392,6^{\mathrm{f}} \pm 4,2$ \\
\hline $\mathrm{K} 20$ & 30 & - & 0,0 & $101,8^{\mathrm{d}} \pm 1,5$ & 0,7 & $7,24^{\mathrm{f}} \pm 0,01$ & $389,5^{\mathrm{f}} \pm 3,1$ \\
\hline 1 & 4 & $6,22 \pm 5,61$ & 0,0 & $101,1^{\mathrm{d}} \pm 4,8$ & 1,4 & $7,32^{\mathrm{e}} \pm 0,04$ & $376,1^{\mathrm{f}} \pm 1,5$ \\
\hline 2 & 10 & $6,10 \pm 5,18$ & 0,0 & $100,6^{\mathrm{d}} \pm 3,8$ & 1,8 & $7,27^{\mathrm{d}} \pm 0,01$ & $377,6^{\mathrm{e}} \pm 3,2$ \\
\hline 3 & 15 & $6,71 \pm 5,87$ & 0,0 & $97,3^{\mathrm{dd}} \pm 1,5$ & 5,1 & $7,13^{\mathrm{d}} \pm 0,02$ & $358,6^{\mathrm{c}} \pm 0,8$ \\
\hline 4 & 20 & $7,83 \pm 6,48$ & 0,0 & $83,9^{\mathrm{b}} \pm 4,4$ & 18,1 & $6,72^{\mathrm{b}} \pm 0,05$ & $270,2^{\mathrm{d}} \pm 2,1$ \\
\hline 5 & 30 & $8,03 \pm 7,47$ & 0,0 & $64,2^{\mathrm{a}} \pm 8,2$ & 37,4 & $6,41^{\mathrm{a}} \pm 0,02$ & $265,2^{\mathrm{a}} \pm 6,9$ \\
\hline 6 & 40 & $7,09 \pm 5,32$ & 0,0 & $91,9^{\mathrm{c}} \pm 0,7$ & 10,3 & $7,10^{\mathrm{c}} \pm 0,03$ & $297,8^{\mathrm{b}} \pm 0,8$ \\
\hline 7 & 45 & $4,46 \pm 4,16$ & 0,0 & $95,2^{\mathrm{cd}} \pm 1,9$ & 7,2 & $7,13^{\mathrm{c}} \pm 0,02$ & $304,9^{\mathrm{c}} \pm 3,3$ \\
\hline
\end{tabular}

Objaśnienia / Explanatory notes:

K - próba kontrolna bez dodatku szczepu $S$. carnosus / control sample without $S$. carnosus strain added; K20 - próba kontrolna bez dodatku szczepu S. carnosus inkubowana w ciągu $20 \mathrm{~h} /$ control sample without $S$. carnosus strain added, and incubated for $20 \mathrm{~h}$; $\mathrm{SR}$ - stopień redukcji $\mathrm{NaNO}_{2}$ liczony w stosunku do ilości $\mathrm{NaNO}_{2}$ oznaczonego w próbie $\mathrm{K} / \mathrm{NaNO}_{2}$ reduction degree, calculated based on the amount of $\mathrm{NaNO}_{2}$ determined in $\mathrm{K}$ sample; $\mathrm{T}$ - temperatura inkubacji / temperature of incubation;

* dodatek szczepu $S$. carnosus na poziomie 6,21 log jtk/g przed inkubacją / S. carnosus strain added at level of $6.21 \log \mathrm{CFU} / \mathrm{g}$ prior to incubation.

W tabeli przedstawiono wartości średnie \pm odchylenia standardowe / Table shows mean values and standard deviations; $\mathrm{n}=3$; a - $\mathrm{f}$ - wartości średnie oznaczone rożnymi małymi literami pomiędzy próbami różnią się statystycznie istotnie $(\mathrm{p} \leq 0,05)$ / mean values denoted by different small letters within different samples differ statistically significantly $(\mathrm{p} \leq 0.05)$. 
W pracy badano $\mathrm{pH}$ i potencjał redox w próbkach inkubowanych w przyjętych temperaturach. Obserwowano wzrost stopnia kwasowości podłoża w czasie namnażania się bakterii, co może dowodzić, że bakterie fermentują glukozę w nim zawartą do kwasu mlekowego lub innych kwasów organicznych. Najniższą wartość pH stwierdzono w próbkach inkubowanych w temp. $30^{\circ} \mathrm{C}$.

Taką samą tendencję stwierdzono w przypadku zmian potencjału oksydacyjnoredukcyjnego. Wraz ze wzrostem liczby bakterii obserwowano obniżenie wartości potencjału oksydacyjno-redukcyjnego układu modelowego i redukcję dodanych azotanów(III).

Bakterie z rodzaju Staphylococcus w warunkach ograniczonego dostępu tlenu wykorzystują jako ostateczne akceptory elektronów utlenione związki mineralne, głównie azotany(V). Gøtterup i wsp. [3, 4] wskazują, że niektóre szczepy bakterii, m.in. S. carnosus, S. simulans, S. succinus wykazują również aktywność enzymu reduktazy azotanowej(III), który bierze udział w redukcji azotanów(III). Głównym produktem denitryfikacji jest azot cząsteczkowy, ale w określonych warunkach dochodzi do akumulacji związków pośrednich, tj. $\mathrm{NO}, \mathrm{N}_{2} \mathrm{O}, \mathrm{NH}_{4}{ }^{+}[6]$.

$\mathrm{Na}$ dynamikę powstawania tlenku azotu $\mathrm{z}$ azotanów(III) mogą mieć również wpływ warunki środowiskowe, tj. kwasowość i potencjał oksydacyjno-redukcyjny układu modelowego, zmieniające się pod wpływem aktywności bakterii. Obniżenie pH i potencjału redox środowiska przyspiesza redukcję $\mathrm{NO}_{2}[1,12,17]$. NO może wchodzić w reakcję z peptydami obecnymi w podłożu białkowym lub brać udział w procesie denitryfikacji $[1,2,12]$.

W inkubowanych próbkach nie stwierdzono obecności azotanów(V), co wskazywałoby, że dodany azotan(III) nie ulegał utlenieniu. Wydaje się to jednak mało prawdopodobne. Mechanizm przemian związków azotowych w zastosowanym układzie modelowym może być złożony. Nieprzereagowany NO może wchodzić w reakcje wtórne i utleniać się do $\mathrm{NO}_{2}$ i $\mathrm{NO}_{3}$ [12]. Może również zachodzić dysmutacja $\mathrm{HNO}_{2}$ do $\mathrm{NO}_{3}$ i NO [1].

Dla bakterii z rodzaju Staphylococcus ,łatwiejszym” źródłem azotu są azotany(V) niż azotany(III). Azotany(V) częściej niż azotany(III) wykorzystywane są przez te bakterie w procesie oddychania beztlenowego [3, 6]. Gotterup i wsp. [3, 4] wykazali, że wybrane szczepy $S$. carnosus charakteryzowały się kilkudziesięciokrotnie większą aktywnością wytwarzania enzymu reduktazy azotanowej(V) niż azotanowej(III). Dla przykładu aktywność wytwarzania reduktazy azotanowej(V) w przypadku jednego z badanych szczepów $S$. carnosus (504) wynosiła $532 \pm 9 \mathrm{nmol} \cdot \mathrm{min}^{-1} \cdot \mathrm{ml}^{-1}$ natomiast, reduktazy azotanowej(III) $-7 \pm 1,9 \mathrm{nmol} \cdot \mathrm{min}^{-1} \cdot \mathrm{ml}^{-1}$.

Azotany(V), które potencjalnie powstały w wyniku przemian azotanów(III) w zastosowanym układzie modelowym, mogły być wykorzystane przez bakterie w procesie denitryfikacji. 
Efektywność redukcji azotanów(III) przez zastosowaną kulturę była zależna od tempa wzrostu i liczby komórek bakterii mierzonej w próbkach po inkubacji. Im wyższa była liczba komórek bakterii, tym stopień redukcji azotanów(III) w próbce był większy (tab. 1). Zależność tę stwierdzili również inni badacze, którzy wskazują, że maksymalną syntezę enzymu reduktazy azotanowej(V) i (III) przez bakterie z rodzaju Staphylococcus obserwuje się w okresie wzrostu wykładniczego bakterii $[3,10,11]$. Nie zaobserwowano natomiast znaczącego wzrostu liczby komórek bakteryjnych w próbkach inkubowanych w temp. $4,10 \mathrm{i} 15^{\circ} \mathrm{C}$ w stosunku do liczby wprowadzonych bakterii przed inkubacją $(6,21 \mathrm{log} \mathrm{jtk} / \mathrm{g})$. Nie stwierdzono również istotnej redukcji azotanu(III) sodu w zakresie tych temperatur. W próbkach inkubowanych w temp. $45{ }^{\circ} \mathrm{C}$ stwierdzono znaczące obniżenie liczby bakterii po $20 \mathrm{~h}$ inkubacji do 4,46 log jtk/g, co wskazuje na destrukcyjne działanie temperatury na wzrost bakterii (tab. 1). W wariancie tym nie stwierdzono istotnej redukcji azotanu(III) sodu.

$\mathrm{Z}$ danych literaturowych wynika, że bakterie z rodzaju Staphylococcus rosną w stosunkowo szerokim zakresie temperatur $\left(7-48{ }^{\circ} \mathrm{C}\right)$. Różne gatunki Staphylococcus i szczepy bakterii należące do tego samego gatunku, ale wyizolowane $\mathrm{z}$ różnych środowisk, mogą charakteryzować się różną tolerancją wobec temperatury $[3,10,11,19]$. Jak podają Søndergaard i Stahnke [16], optymalna temperatura wzrostu większości szczepów tych bakterii wynosi $35-40{ }^{\circ} \mathrm{C}$. Hać-Szymańczuk i Roman [5] wskazują, że optymalna temperatura wzrostu Staphylococcus to $25-30^{\circ} \mathrm{C}$. Badany szczep rozwijał się W zakresie temperatur wzrostu bakterii z rodzaju Staphylococcus podawanym w literaturze. Niemniej nie stwierdzono znaczącego wzrostu liczby bakterii w temperaturze minimalnej $\left(10^{\circ} \mathrm{C}\right)$ i maksymalnej $\left(45^{\circ} \mathrm{C}\right)$, podawanej przez producenta kultury starterowej. Stwierdzone rozbieżności mogą wynikać z różnic w składzie i parametrach podłoży białkowych (zawartość składników odżywczych, $\mathrm{NaCl}$, wartość pH) użytych w niniejszej pracy, a tych stosowanych przez firmę Chr. Hansen.

Na podstawie przeprowadzonych badań wykazano, że liczba początkowa $S$. carnosus i czas inkubacji miały istotny wpływ $(\mathrm{p} \leq 0,05)$ na szybkość redukcji azotanu(III) sodu (rys. 1). W próbkach, w których zastosowano większą liczbę bakterii $\left(10^{7} \mathrm{jtk} / \mathrm{g}\right)$ zawartość azotanu(III) sodu po 4 i 6 h inkubacji zmniejszyła się statystycznie istotnie $(\mathrm{p} \leq 0,05)$. Natomiast po $20 \mathrm{~h}$ inkubacji w próbkach z początkową liczbą bakterii na poziomie $10^{6} \mathrm{i} 10^{7} \mathrm{jtk} / \mathrm{g}$ stwierdzono zbliżoną zawartość azotanu(III) sodu.

Jak wynika z krzywych opisujących przemiany azotanu(III) w próbkach, czas istotnie wpłynął na szybkość redukcji tych związków, co związane jest najprawdopodobniej z procesem produkcji enzymów przez komórki bakterii (rys. 1).

Badania w układzie modelowym wykazały, że chlorek sodu działał hamująco na komórki bakterii $S$. carnosus i wpłynął istotnie na obniżenie szybkości redukcji azotanu(III). Po 4, 6 i 20 h inkubacji średnia zawartość azotanu(III) sodu w próbkach zawierających 3,0 \% chlorku sodu była istotnie większa od tych zawierających $0,5 \%$ 
chlorku sodu (rys. 2). Taką samą tendencję stwierdzono w przypadku próbek zawierających 2,0 \% chlorku sodu po 4 i 6 h inkubacji.

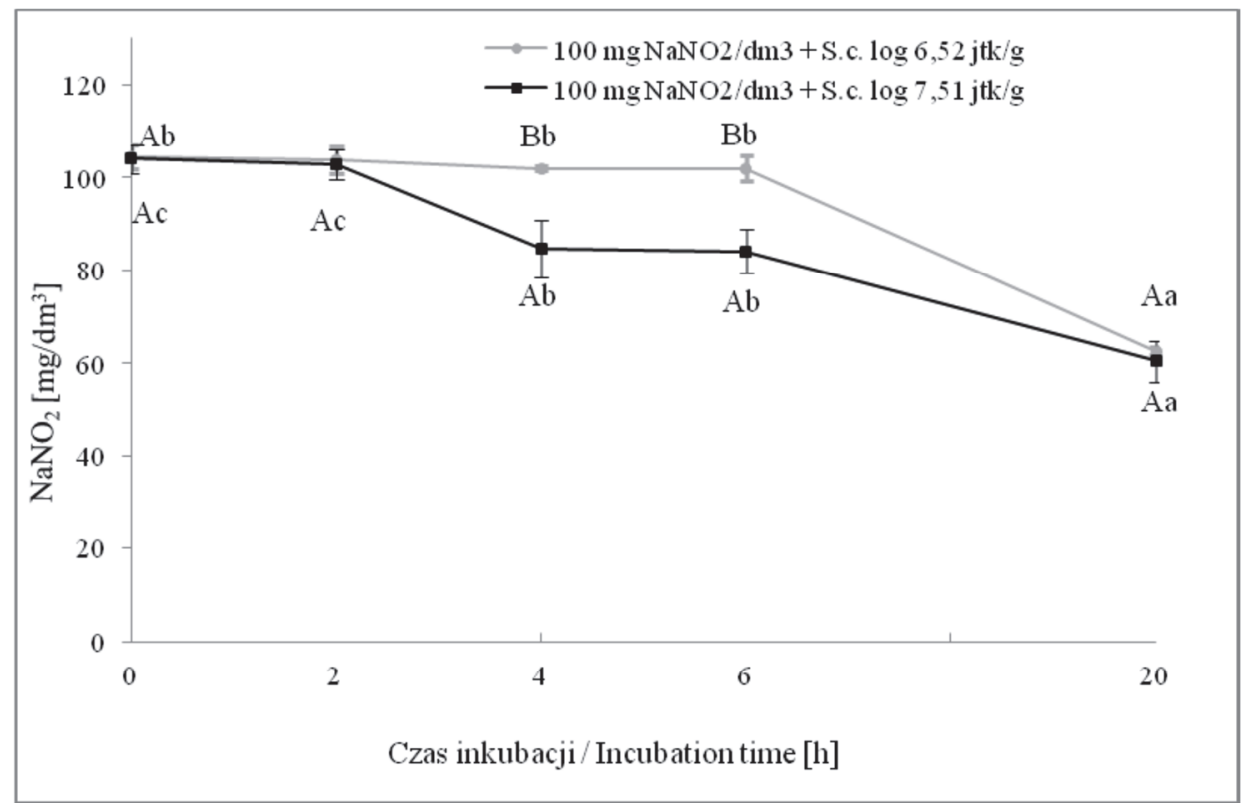

Objaśnienia / Explanatory notes:

$\mathrm{Na}$ wykresie graficznie naniesiono wartości $\overline{\mathrm{x}} \pm \mathrm{SD} /$ Values plotted on the graph are $\overline{\mathrm{x}} \pm \mathrm{SD} ; \mathrm{n}=3$; Wartości średnie oznaczone rożnymi małymi literami (a - c) w obrębie tej samej próby i dużymi literami (A - C) pomiędzy próbami różnią się statystycznie istotnie $(\mathrm{p} \leq 0,05)$ / Mean values denoted by different small letters $(\mathrm{a}-\mathrm{c})$ within the same sample or by capital letters $(\mathrm{A}-\mathrm{C})$ within different samples differ statistically significantly $(\mathrm{p} \leq 0.05)$.

Rys. 1. Wpływ czasu inkubacji i początkowej liczby bakterii Staphylococcus carnosus na redukcję azotanu(III) sodu w temp. $30^{\circ} \mathrm{C}$

Fig. 1. Effect of incubation time and initial number of Staphylococcus carnosus bacteria on reduction of nitrate(III) at a temperature of $30^{\circ} \mathrm{C}$

Negatywny wpływ chlorku sodu na szybkość redukcji azotanu(III) sodu przez badany szczep może wynikać z hamującego działania tej substancji na komórki bakterii w zastosowanym układzie modelowym. Na podstawie analizy liczby bakterii dodanego szczepu w wariantach doświadczalnych w poszczególnych godzinach inkubacji wykazano, że średnia liczba komórek bakteryjnych była niższa w wariantach zawierających 2,0 i 3,0 \% chlorku sodu niż w próbkach o zawartości $0,5 \% \mathrm{NaCl}$ po 2 , 4 i 6 h inkubacji. Średnia liczba komórek bakterii w próbkach zawierajcych 3,0 \% chlorku sodu po 2, 4 i 6 h inkubacji wyniosła kolejno [log jtk/g]: 7,48, 7,62 i 7,89, w próbkach zawierających $2,0 \%$ chlorku sodu - $[\log \mathrm{jtk} / \mathrm{g}]: 7,45,7,90$ i 8,04 , natomiast $\mathrm{w}$ próbkach zawierających $0,5 \%$ chlorku sodu - [log jtk/g]: 7,63, 8,18 
i 8,45. Średnia liczba komórek bakterii po $20 \mathrm{~h}$ inkubacji wynosiła odpowiednio [log jtk/g]: 8,08 w próbkach z 0,5\% $\mathrm{NaCl}, 8,43$ - w próbkach z 2,0 \% $\mathrm{NaCl}$ i 7,91 w próbkach z 3,0\% $\mathrm{NaCl}$.

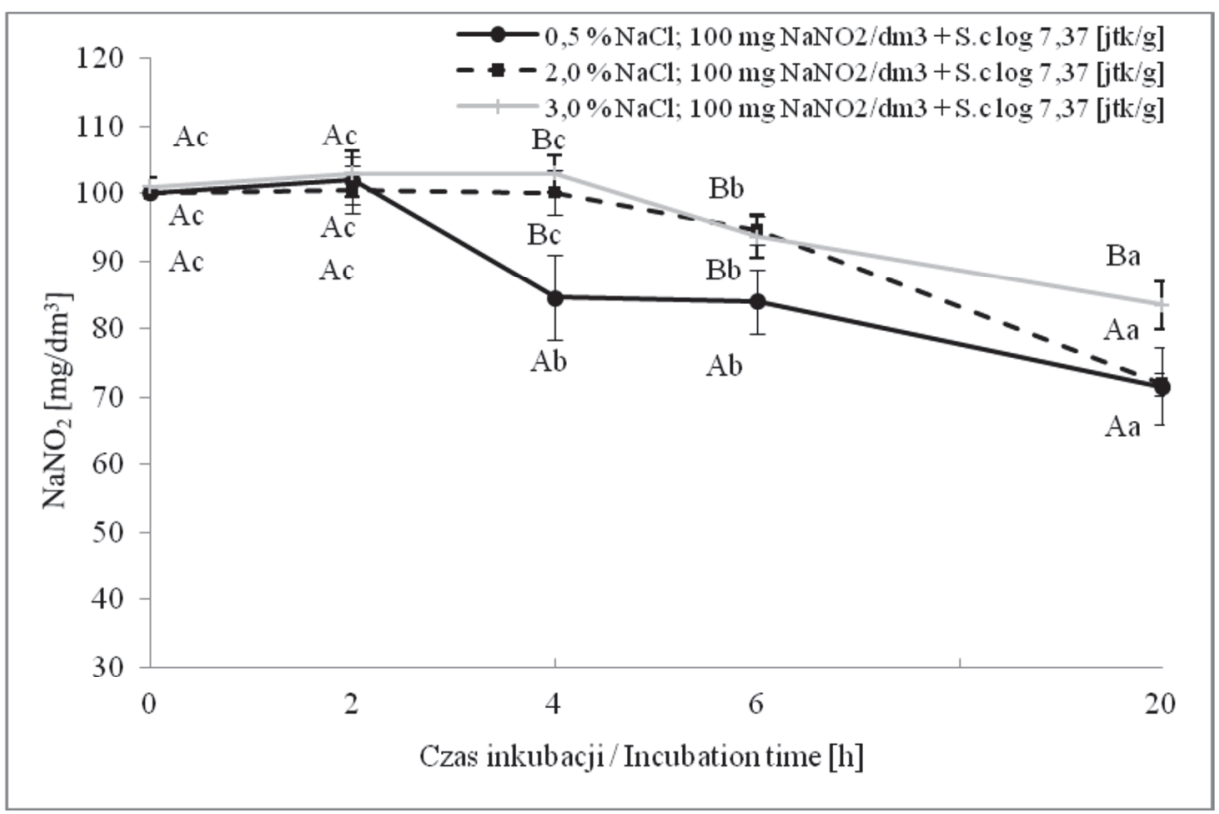

Objaśnienia jak pod rys. 1. / Explanatory notes as in Fig. 1.

Rys. 2. Wpływ stężenia chlorku sodu na redukcję azotanu(III) sodu przez Staphylococcus carnosus podczas inkubacji w temp. $30^{\circ} \mathrm{C}$

Fig. 2. Effect of sodium chloride concentration on reduction of nitrate(III) by Staphylococcus carnosus during incubation at a temperature of $30^{\circ} \mathrm{C}$

Dane literaturowe wskazują, że bakterie z rodzaju Staphylococcus charakteryzują się wysoką opornością na sól $[7,9]$. Przy interpretacji otrzymanych wyników należy wziąc pod uwagę to, że zastosowany w przeprowadzonych badaniach układ modelowy zawierał oprócz chlorku sodu azotan(III) sodu. Tak więc wysoko prawdopodobne jest, że substancje te działały synergistycznie i wpływały hamująco na komórki bakterii.

W wariantach doświadczalnych, w których zastosowano większe dawki wielofosforanów (4,9 i 6,4 $\mathrm{g} \mathrm{P}_{2} \mathrm{O}_{5} / \mathrm{dm}^{3}$ ) obserwowano, że liczba bakterii po 2, 4, 6 i $20 \mathrm{~h}$ inkubacji była mniejsza od tych, w których fosforan był na poziomie $1,2 \mathrm{P}_{2} \mathrm{O}_{5} \mathrm{~g} / \mathrm{dm}^{3}$ (rys. $3)$. 
Stwierdzono, że średnia zawartość azotanu(III) sodu w próbkach inkubowanych przez 4, 6 i 20 h była mniejsza w wariancie, w którym poziom fosforanów był najmniejszy $\left(1,2 \mathrm{P}_{2} \mathrm{O}_{5} \mathrm{~g} / \mathrm{l}\right) \mathrm{w}$ porównaniu z próbkami, w których średnia zawartość fosforanów była na wyższym poziomie $\left(4,9\right.$ i $\left.6,4 \mathrm{~g} \mathrm{P}_{2} \mathrm{O}_{5} / 1\right)$. Statystycznie potwierdzono zależność pomiędzy próbkami zawierającymi 1,2 i $6,4 \mathrm{~g} \mathrm{P}_{2} \mathrm{O}_{5} / \mathrm{l}(\mathrm{p} \leq 0,05)$ (rys. 4).

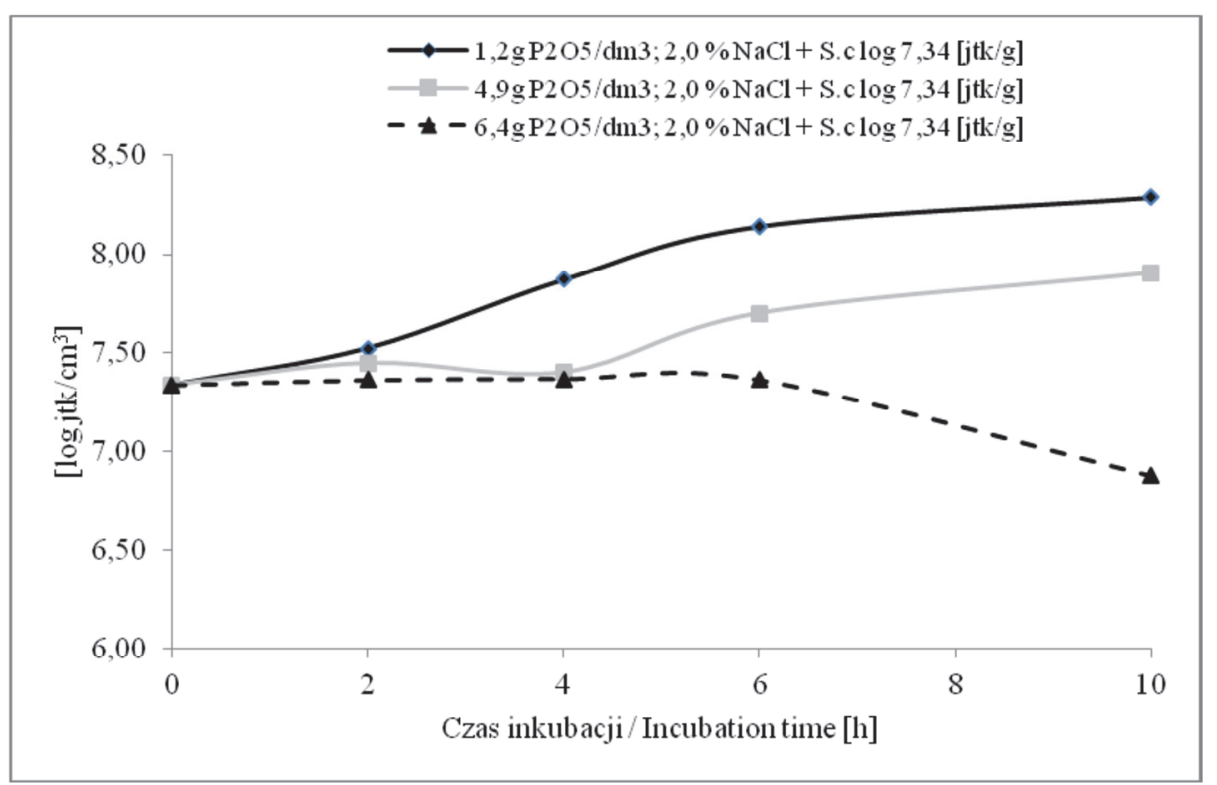

Objaśnienia / Explanatory notes:

Na wykresie graficznie naniesiono wartości średnie $\overline{\mathrm{x}} /$ Mean values plotted on the graph are $\overline{\mathrm{x}}$.

Rys. 3. Wpływ stężenia wielofosforanów na liczbę bakterii Staphylococcus carnosus podczas inkubacji w temp. $30^{\circ} \mathrm{C}$

Fig. 3. Effect of concentration of multi-phosphates on number of Staphylococcus carnosus bacteria during incubation at a temperature of $30^{\circ} \mathrm{C}$

Wykazano negatywny wpływ wielofosforanów na redukcję azotanu(III) sodu, co przypuszczalnie spowodowane było ich hamującym działaniem na wzrost bakterii denitryfikujących. Znane jest działanie bakteriostatyczne wielofosforanów, szczególnie w stosunku do bakterii Gram-dodatnich, do których zalicza się użyte w pracy szczepy bakterii denitryfikujących. Uważa się, że wielofosforany tworzą trwałe, nierozpuszczalne kompleksy z kationami dwuwartościowymi, które nie są przyswajane przez bakterie. Jest to działanie bakteriostatyczne, które polega na rywalizacji o składniki pożywki [20]. 


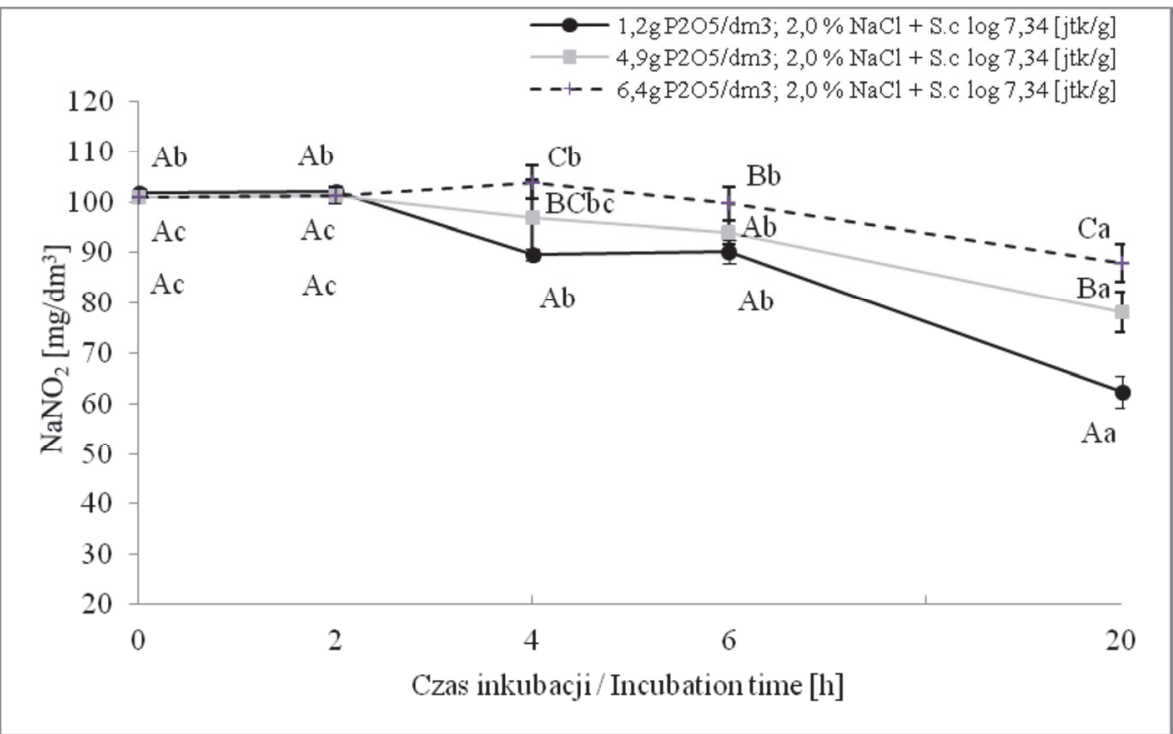

Objaśnienia jak na rys 1. / Explanatory notes as in Fig. 1.

Rys. 4. Wpływ stężenia wielofosforanów na redukcję azotanu(III) sodu przez Staphylococcus carnosus podczas inkubacji w temp. $30^{\circ} \mathrm{C}$

Fig. 4. Effect of concentration of multi-phosphates on reduction of nitrate(III) by Staphylococcus carnosus during incubation at a temperature of $30^{\circ} \mathrm{C}$

\section{Wnioski}

1. Na podstawie przeprowadzonych badań modelowych wykazano, że szczep bakterii Staphylococcus carnosus redukuje azotan(III) sodu w zakresie temperatur: 20 $40{ }^{\circ} \mathrm{C}$.

2. Stwierdzono, że chlorek sodu (2,0 \%) i wielofosforany $\left(\mathrm{P}_{2} \mathrm{O}_{5}: 4,9 \mathrm{~g} / \mathrm{kg}\right.$ i $\left.6,4 \mathrm{~g} / \mathrm{kg}\right)$ mają negatywny wpływ na wzrost bakterii i redukcję azotanów(III) sodu przez Staphylococcus carnosus.

\section{Literatura}

[1] Arneth W.: Chemische Grundlagen der Umrötung. Fleischwirtschaft, 1998, 8, 868-874.

[2] Cassens R.G.: Use of sodium nitrite in cured meats today. Food Technology, 1995, 49 (7), 72-80.

[3] Gøtterup J., Olsen K., Knochel S., Tjener K., Stahnke L.H., Møller J.K.S.: Relationship between nitrate/nitrite reductase activities in meat associated staphylococci and nitrosylmyoglobin formation in a cured meat model system. Inter. J. Food Microbiol., 2007, 120, 303-310.

[4] Gøtterup J., Olsen K., Knøchel S., Tjener K., Stahnke L.H., Møller J.K.S.: Colour formation in fermented sausages by meat-associated staphylococcus with different nitrite- and nitrate- reductase activities. Meat Sci., 2008, 78, 492-501. 
[5] Hać-Szymańczuk E., Roman J.: Charakterystyka drobnoustrojów wchodzących w skład kultur starterowych i ich wykorzystanie w przetwórstwie mięsa. Post. Techn. Przetw. Spoż., 2009, 19/35 (2), 131-135.

[6] Hammes W.P.W.: Metabolism of nitrate in fermented meats: The characteristic feature of a specific group of fermented foods. Food Microbiology, 2012, 29, 151-156.

[7] Hammes W.P., Bosh I., Wolf G.: Contribution of Staphylococcus carnosus and Staphylococcus piscifermentans to the fermentation of protein foods. J. Appl. Bacteriol., Symposium Suppl., 1995, 79, 76-83.

[8] Kitzman P., Tyszkiewicz I.: Przeprowadzenie prac rozwojowych w zakresie stosowania obniżonych dawek azotynów. Centralny Program Badawczo-Rozwojowy. Nr 10.7. IPMiT, Warszawa 1990, ss. $72-55$.

[9] McMeekin T.A., Chandler R.E., Doe P.E., Garland C.D., Olley J., Putro S., Ratkowsky D.A.: Model of combined effect of temperature and salt concentration/water activity on the growth rate of Staphylococcus xylosus. J. Appl. Bacteriol., 1987, 62, 543-550.

[10] Neubauer H., Götz F.: Physiology and interaction of nitrate and nitrite reduction in Staphylococcus carnosus. J. Bacteriol., 1996, 178, 2005-2009.

[11] Pantel I., Lindgren P.E., Neubauer H., Götz F.: Identification and characterization of the Staphylococcus carnosus nitrate reductase operon. Molecular Genetics and Genomics, 1998, 259, 105-114.

[12] Parthasarathy D.K., Bryan N.S.: Sodium nitrite: The "cure" for nitric oxide insufficiency. Meat Sci., 2012, 92, 274-279.

[13] PN-EN ISO 12014-3:2006. Artykuły żywnościowe. Oznaczanie zawartości azotanów i/lub azotynów.

[14] Schleifer K.H., Fischer U.: Description of a new species of the genus Staphylococcus: Staphylococcus carnosus. Int. J. Systematic Bacteriol., 1982, 32 (2), 153-156.

[15] Siu D., Henshall A.: Ion chromatographic determination of nitrate and nitrite in meat products. J. Chromatography, 1998, 804, 156-160.

[16] Søndergaard A.K., Stahnke L.H.: Growth and aroma production by Staphylococcus xylosus, S. carnosus and S. equorum - a comparative study in model system. Int. J. Food Microbiol., 2002, 75, 99109.

[17] Szymański P.: Zastosowanie wybranych szczepów bakterii denitryfikujących w procesie peklowania azotynowego mięsa. Praca doktorska, 2015. Szkoła Główna Gospodarstwa Wiejskiego, Wydział Nauk o Żywieniu Człowieka i Konsumpcji, Warszawa 2015.

[18] Szymański P., Kołożyn-Krajewska D.: Wpływ szczepu bakterii Staphylococcus carnosus ATCC 51365 zastosowanego w procesie peklowania mięsa na wybrane cechy jakościowe modelowego produktu mięsnego. Żywność. Nauka. Technologia. Jakość. 2016, 4 (107), 53-65.

[19] Talon R., Walter D., Chartier S., Barriere C., Montel M.C.: Effect of nitrate and incubation conditions on the production of catalase and nitrate reductase by staphylococci. Int. J. Food Microbiol., 1999, 52, 47-56.

[20] Tyszkiewicz T., Wawrzyniewicz M., Borys A.: Factors influencing physiological phosphorus content in pork meat. Acta Agrophysica 2011, 17 (2), 387-393. 


\title{
EFFECTIVENESS OF STAPHYLOCOCCUS CARNOSUS BACTERIA IN REDUCING SODIUM NITRATE(III) IN MODEL SYSTEM
}

\author{
$\mathrm{Sum}$ m a r y
}

The objective of the research study was to assess the effect of some selected conditions and additional substances used in the production of meat batters on reducing sodium nitrate (III) by Staphylococcus carnosus obtained from an industrial vaccine developed to be used in the production of fermented meat products (Bactoferm S-B-61). The study was conducted in a model system, i.e. a TBS liquid protein medium. The bacterial culture was reproduced on a TSB liquid protein medium for $20 \mathrm{~h}$, at $30^{\circ} \mathrm{C}$. In the individual experiments, there were used bacteria from the third passage. The effect was investigated of $S$. carnosus on reducing sodium nitrate(III) under certain conditions (time, temperature, and initial number of bacteria). Sodium chloride and polyphosphates were added as additional substances. In every experiment, before and after incubation, there were determined nitrate(III) and nitrate(V), S. carnosus, $\mathrm{pH}$, and redox potential. The experiments were performed in three parallel repeats. Based on the analyses performed, it was found that the strain of Staphylococcus carnosus bacteria reduced sodium nitrate at temperatures between 20 and $40{ }^{\circ} \mathrm{C}$. The increase in the initial number of bacteria to $10^{7} \mathrm{cfu} / \mathrm{cm}^{3}$ significantly affected the reduction of nitrate(III). It was reported that along with the increase in the number of bacteria, the acidity degree of the protein medium increased, whereas the redox potential of the model system decreased. Sodium chloride and polyphosphates had an inhibiting effect on the growth and bacterial activities within the reduction range of sodium nitrate(III). It was found that the strain of $S$. carnosus bacteria reduced sodium nitrate(III) but only under certain environmental conditions.

Key words: nitrates (III), meat curing, and Staphylococcus carnosus, reduction of nitrates (III) 